\title{
PERLINDUNGAN HUKUM KONSUMEN ATAS INFORMASI HARGA PADA PRODUK MINUMAN
}

\author{
M Syahrul Bahri, I Nyoman Putu Budiartha, Ni Made Puspasutari Ujianti \\ Fakultas Hukum Universitas Warmadewa, Denpasar-Bali, Indonesia \\ syahrulbahri17@gmail.com, budiarthaputu59@gmail.com, puspa.niwapong@gmail.com
}

\begin{abstract}
Abstrak
Minuman merupakan salah satu keperluan utama manusia di dunia yang harus terpenuhi untuk beraktivitas, setiap manusia harus memenuhi kebutuhannya terutama minuman baik itu jumlahnya atau dalam perihal kesehatan minuman tersebut. Oleh karena itu Negara harus memberikan keamanan bagi masyarakatnya tanpa terkecuali baik itu berkaitan dengan pengawasan ataupun mengatur peredarannya. Penelitian ini bertujuan untuk menjelaskan perlindungan hukum bagi konsumen atas informasi harga produk minuman yang tertera pada kemasan dan menjelaskan upaya penyelesaian mengenai perbedaan harga pada kemasan dengan harga jual yang dibayar. Penelitian ini menggunakan penelitian hukum normatif, dengna pendekatan yuridis melalui metode hermenutika. Data yang digunakn adalah data sekunder dan primer yang dianalisis secara kualitatif. Hasil penelitian menunjukkan bahwa pemerintah telah memberi perlindungan konsumen atas pemberian informasi yang tepat keharusan yang dilakukan pelaku usaha serta larangan yang tidak boleh dilanggarnya. Tanggung jawab pelaku usaha untuk menyelesaikan sengketa dapat ditempuh melalui jalur di luar pengadilan maupun jalur pengadilan. Faktor- faktor yang mempengaruhi terjadinya produk yang memiliki nominal berbeda dari harga pada kemasan terdiri dari faktor internal dan faktor eksternal. Jika terjadi perbedaan harga pada kemasan dengan saat pembayaran maka yang akan dibayarkan adalah biaya yang paling murah.
\end{abstract}

Kata kunci: Perlindungan Hukum, Konsumen, Harga Kemasan

\begin{abstract}
Drinking is one of the main needs of humans in the world that must be fulfilled for activity. Every human being must meet his needs, especially drinks, whether in quantity or in terms of the health of the drink. Therefore, the State must provide security for its people without exception whether it is related to supervision or regulating its circulation. This study aims to explain the legal protection for consumers for information on the price of beverage products listed on the packaging and to explain the resolution efforts regarding the difference between the price on the packaging and the selling price paid. This research used normative legal research, with a juridical approach through the hermenutic method. The data used were secondary and primary data which were analyzed qualitatively. The result of the research showed that the government has provided consumer protection for the provision of accurate information by means of obligations imposed by business actors as well as prohibitions that cannot be violated. The responsibility of business actors to resolve disputes can be pursued through channels outside the court as well as through court channels. The factors that influence the occurrence of a product that is nominally different from the price on the packaging consist of internal factors and external factors. If there is a difference in price on the package and at the time of payment, the cheapest fee will be paid.
\end{abstract}

Keywords: Legal Protection, Consumer, Packaging Price

\section{PENDAHULUAN}

Perkembangan jaman di Indonesia mengalami berbagai kemajuan yang sangat pesat sehingga mengakibatkan banyaknya permasalahan yang timbul. Misalnya masalah mengenai perlindungan terhadap konsumen di bidang perdagangan. Dengan demikian negara harus menjamin dan memberikan keamanan bagi masyarakatnya tanpa terkecuali baik itu berkaitan dengan pengawasan ataupun mengatur peredarannya (Ali, 2011).

Untuk menjaga kesehatan perlu adanya perlindungan terhadap konsumen dikarenakan hak yang melekat dari semua masyarakat wajib dijamin oleh Negara sesuai amanat Undang-undang dasar Negara republik Indonesia Tahun 1945. Pemberian perlindungan tersebut bertujuan untuk mendorong pembangunan dan sumber daya alam yang sangat mumpuni. Pasal 27 ayat (2) UUD NRI Tahun 1945 menyebutkan bahwa tiap-tiap warga Negara berhak atas pekerjaan dan penghidupan yang layak bagi 
kemanusiaan. Untuk mendapatkan kehidupan yang layak dan terwujudnya kesejahteraan diperlukan upaya penyelarasan baik itu barang dan jasa dalam kapasitas yang memadai kualitas yang bagus (Sidabalok, 2006).

Dalam usaha untuk perlindungan konsumen pemerintah sudah menetapkan Undang-Undang Nomor 8 Tahun 1999 tentang Perlindungan Konsumen (UUPK). Dengan adanya peraturan ini maka sengketa konsumen dengan pelaku usaha diharapkan dapat diminimalisir sehingga hak konsumen dapat terpenuhi. Konsumen berhak atas suatu kepastian mengenai informasi yang jelas terhadap barang tersebut hak mendapatkan informasi yang benar dimaksudkan supaya konsumen mengetahui informasi yang jelas mengenai produk maupun jasa tersebut sehingga konsumen dapat memilih produk barang maupun jasa sesuai dengan kebutuhan dan keinginannya (Tobing, 2015).

Dalam kemasan produk terdapat informasi yang dapat konsumen jadikan sebagai penentuan antara pilihan yang ada untuk membeli dan mengkonsumsinya. Informasi yang tidak jelas mengakibatkan kerugian bagi konsumen (Shofie, 2000). Dengan maraknya permasalahan pada produk minuman yang terjadi di Indonesia sampai saat ini masih banyak ditemukannya masalah yang sama yang tidak mematuhi aturan yang telah dibuat mengenai pencantuman harga pada produk. Pengawasan pemerintah, lembaga konsumen terhadap pelaku usaha dan masyarakat sudah dilakukan bebarapa upaya sehingga dibuat beberapa peraturan yang berkaitan tentang perlindungan konsumen, meskipun demikian sampai saat ini masih terdapat pengawasan yang belum efektif (Poernomo, 2020). Penelitian ini bertujuan untuk menjelaskan perlindungan hukum bagi konsumen atas informasi harga produk minuman yang tertera pada kemasan dan menjelaskan upaya penyelesaian mengenai perbedaan harga pada kemasan dengan harga jual yang dibayar

\section{METODE PENELITIAN}

Penelitian yang digunakan adalah penelitian hukum normatif, dengan pendekatan yuridis melalui metode hermenutika (Waluyo, 2002). Data yang digunakn adalah data sekunder dan primer yang dianalisis secara kualitatif deskriptif. Bahan hukum primer adalah bahan hukum yang utama yang menjadi dasar kajian dalam penelitian ini sedangkan bahan hukum sekunder yaitu bahan hukum yang digunakan untuk menunjang atau membantu dalam memberikan pemahaman-pemahaman dan gambaran-gambaran serta teori-teori hukum yang digunakan untuk mengulas dan memecahkan persoalan-persoalan yang akan diteliti. Untuk memperoleh data digunakan teknik inventarisasi atau penelusuran bahan hukum yang bersangkutan lalu diklasifikasi atau dikelompokan dan didokumentasikan, dicatat, dikutip diringkas diulas sesuai kebutuhan dengan pendekatan kualitatif (Sugiyono, 2013).

\section{HASIL DAN PEMBAHASAN}

\section{Perlindungan Konsumen Mengenai Informasi Produk Minuman}

Konsumen mendapatkan sebuah perlindungan jika dilihat melalui hukum materiil maupun formil. Kemajuan keilmuan bidang teknologi merupakan roda utama pergerakan produktifitas ataupun keefisienan pelaku usaha barang atau jasa yang dibuatnya untuk menjadi target usahanya. Perihal untuk menggapai hal demikian akhirnya secara langsung maupun tidak secara langsung para konsumen yang secara umum menerima dampaknya (Shidarta, 2000).

Meskipun dalam UUPK khusus berbicara mengenai pemberian perlindungan kepada konsumen tetapi dalam UUPK tidak saja membahas pemberian perlindungan terhadap konsumen semata tetapi juga hak bagi pelaku usaha juga diberi sorotan akan tetapi dengan maraknya kasus yang menjadikan konsumen sebagai objek kesewenang-wenangan oleh para pelaku usaha hal tersebut mengakibatkan perlindungan yang diberikan pada konsumen lebih terlihat. Perkembanagan globalisasi ikut serta memperhatikan mengenai hal tersebut yang tertuang dalam resolusi perserikatan bangsa-bangsa Nomor 39/248 tentang Perlindungan Konsumen beberapa hak yang penting harus dilindungi terhadap kepentingan konsumen antara lain:

1) Diberikannya perlindungan terhadap konsumen dari adanya ancaman kesehatan serta keamanannya

2) Diberikannya perlindungan akan keadaan sosial ekonomi seorang konsumen

3) Terdapat informasi yang cukup untuk bisa konsumen melakukan sebuah pilihan yang tepat menurutnya

4) Pendidikan konsumen 
5) Terdapatnya cara penggantian jika konsumen merasa rugi. Mengenai untuk membuat sebuah kelompok konsumen atau kelompok lainnya diberikan kebebasan serta peluang terhadap kelompok tersebut untuk ikut memberi suara pendapatnya mengenai suatu cara untuk mengambil sebuah keputusan yang akan berdampak kepada kepentingan mereka juga.

Menurut Susanto, (2008) menjelaskan tentang sendi-sendi pokok pengaturan perlindungan konsumen yaitu:

a) Kedudukan yang sama antara konsumen maupun pelaku usaha

b) Hak yang dimiliki konsumen

c) Kewajiban yang dimiliki pelaku usaha

d) Terkait dengan pembangunan sosial perlindungan terhadap konsumen harus berperan penting

e) Dalam menjalankan bisnis yang sehat konsumen harus mendapatkan perlindunga perihal promosi barang atau jasa harus adanya keterbukaan informasi

f) Diperlukannya keaktifan dari pemerintah

g) Diperlukannya keikutsertaan masyarakat

h) Perlindungan konsumen perlu adanya suatu yang baru di bidang hukum dalam berbagai sektor

i) Mengenai konsep diberikannya perlindungan terhadap konsumen perlu diberikan pembinaan sikap.

Dibuatnya UUPK serta segala alat hukum yang lain menyebabkan para konsumen mempunyai kedudukan hak yang sama serta konsumen dapat mengajukan keberatannya apabila haknya ada yang dilanggar oleh para pelaku usaha. Pertanggung jawaban pelaku usaha yaitu dalam hal ini pengelola toko tempat menjual minuman adalah mengganti semua kerugian yang didapatkan oleh konsumen. Perbuatan seperti itu sebagai bentuk tanggung jawab pelaku usaha atas kerugian yang dialami oleh konsumen baik materi maupun non materi hal tersebut dapat dilindungi oleh beberapa aturan yang telah dibuat. Produk yang memiliki harga pada kemasan berbeda dengan saat pembayaran dilakukan merupakan tanggung jawab mutlak pelaku usaha yaitu pemilik toko. Mengenai hal tersebut yaitu jual beli minuman dari tangan pelaku usaha ke konsumen jika terdapat permasalahan dapat diselesaikan melalui jalur pengadilan maupun diluar pengadilan.

\section{Upaya Penyelesaiannya Masalah Perbedaan Harga pada Kemasan dengan Pada Saat Pembayaran}

Pada prinsipnya seluruh manusia memerlukan barang atau jasa untuk memenuhi kebutuhan hidupnya. Apabila dilihat dari strukturnya kebetuhan dapat dibagi menjadi kebutuhan primer, sekunder dan tersier. Dikarenakan akan banyaknya kebutuhan yang diperlukan setiap manusia sehingga mereka akan melakukan usaha yang maksimal untuk memenuhi kebutuhannya itu baik itu barang ataupun jasa serta kebutuhan tersebut juga dapat diperjual belikan oleh para pelaku usaha.

Perihal mengelola usaha baik jual beli tidak akan lepas akan adanya permasalahan harga. Harga sangatlah penting dalam hal menggaet keinginan konsumen dalam hal daya beli akan barang ataupun produk, harga dapat dijadikan penentu akan kualitas barang tersebut. Seiring meningkatnya harga akan barang atau produk maka akan sebanding dengan kualitas yang akan didapatkan ataupun sebaliknya harga menurun akan sebanding dengan turunnya kualitas yang didapatkan. Di indonesia harga dipatok dengan Rupiah dengan itu jika ingin memiliki suatu barang atau produk yang diinginkan konsumen maka konsumen harus membayarnya kepada pelaku usaha.

Dalam menawarkan dan menjual produk, pelaku usaha dilarang memberikan informasi yang tidak benar kepada konsumen mengenai harga suatu produk barang yang dijualnya kepada konsumen hal ini diatur dalam Pasal 10 UUPK. Berdasarkan pasal tersebut harga yang disampaikan kepada konsumen harus sesuai dengan harga yang ditetapkan oleh pelaku usaha pada kemasan produk saat melakukan transaksi pembayaran. Dalam memberikan informasi tentang harga tersebut harus disampaikan secara jelas agar konsumen mengetahui informasi harga, pelaku usaha dapat menetapkan harga harus dicantumkan pada kemasan produk. Tujuan utama dari penetapan harga yang dicantumkan ini pada produk suatu barang guna memberikan ketransparanan akan harga yang diberikan serta memudahkan para konsumen akan melihat informasi harga barang tersebut sehingga dapat membandingkannya dengan para penjual kompetitornya dengan begitu konsumen dapat memilih yang mana akan dibelinya dengan harga yang lebih

baik. 
Menurut Willy \& Nurjanah, (2019) Faktor-faktor yang mempengaruhi pelaku usaha terhadap terjadinya produk yang diklaim memiliki nominal berbeda pada saat pembayaran dari harga pada kemasan yaitu:

1. Faktor Internal

Pelaku usaha dalam hal ini pemilik toko atau pegawai toko tidak sengaja melakukan perbuatan curang misalkan pegawai toko lalai dalam menjalankan kewajibannya perihal penyaluran informasi yang sebenarnya ataupun sejelas mungkin perihal harga produk barang yang ditawarkan atau dijualkan kepada konsumen. Pemilik toko atau pegawai toko lupa untuk memperbaharui atau menempelkan harga yang sama pada kemasan produk dengan saat melakukan transaksi pembayaran sehingga menimbulkan harga yang berbeda yang harus dibayar oleh konsumen. Ataupun perbuatan oknum pemilik toko usaha sengaja menjebak konsumen dengan menempelkan harga murah pada kemasan produk yang berbeda pada saat melakukan transaksi pembayaran di kasir yang ternyata harganya lebih mahal.

2. Faktor Eksternal

Mengenai adanya oknum konsumen dapat melakukan pencabut label harga pada kemasan produk lalu digantinya dengan label harga yang lebih murah dari harga yang seharusnya dibayarkan. Oknum konsumen dapat melakukan hal tersebut dimaksudkan agar mendapatkan harga semurah mungkin sehingga budget keuangan dapat ditekan. Hal tersebut juga didukung karena minimnya penjagaan baik dari pemilik toko atau pegawai toko sehingga oknum tersebut mendapat celah melakukan tindakan tersebut.

Dalam menjual produk barangnya, pelaku usaha dilarang mencantumkan harga yang berbeda pada produk dan pada saat melakukan transaksi pembayaran. Pelaku usaha dilarang menyampaikan informasi yang salah mengenai harga suatu produk barang maupun harga suatu jasa. Pelaku usaha harus bersikap jujur yang menunjukan itikad baik dan bersifat terbuka mengenai informasi yang berkaitan dengan harga atau tarif atas produk yang ditawarkan kepada konsumen. Sehingga dalam hal ini konsumen tidak dirugikan atas informasi mengenai harga produk barang tersebut. Pentingnya informasi terhadap konsumen yaitu agar konsumen dapat terhindar dari kesalahan dalam menilai suatu gambaran terhadap produk barang tersebut.

Mengenai informasi tentang harga diatur dalam Permendagri 35 Tahun 2013 Berdasarkan ini semua harga barang maupun jasa yang dijual oleh pelaku usaha harus mencantumkan harga secara jelas tertulis yang dilekatkan atau ditempelkan pada barang atau kemasan sehingga konsumen mengetahui harga sesungguhnya barang tersebut. Dalam UUPK tidak mengatur tentang memperdagangkan produk barang maupun jasa dengan tarif berbeda antara dikemasan produk dan pada saat melakukan transaksi pembayaran pada kasir yang dilakukan oleh pelaku usaha. Permendagri 35 Tahun 2013 merupakan payung hukum terhadap konsumen yang mengalami perbuatan curang dari para pelaku usaha dalam perbedaan harga pada kemasan produk dengan pada saat melakukan transaksi pembayaran di kasir. Dalam pasal ini ditentukan bahwa konsumen berhak membayar dengan harga yang termurah atau harga yang terendah. Dengan adanya payung hukum mengenai perbedaan harga maka konsumen tidak dirugikan atas informasi yang tidak benar tentang perbedaan harga tersebut.

Akibat hukum untuk para pelaku usaha yang melakukan kecurangan yang menyesatkan konsumen mengenai harga barang dan memberikan informasi yang tidak benar yang mencerminkan itikad tidak baik telah melanggar Pasal 10 UUPK diancam pidana penjara selama 5 tahun dan pidana denda sebanyak Rp 2.000.000.000 00 hal tersebut dijelaskan dalam Pasal 62 UUPK. Bagi para pelaku usaha yang tidak mencantumkan harga dikenakan sanksi denda yaitu dicabutnya izin usaha dibidang perdagangan yang dilakukan oleh pejabat yang berwenang sesuai yang termuat dalam Pasal 9 Permendagri 35 Tahun 2013. UUPK menjelaskan terdapat 2 (dua) jalur yang dapat dilakukan untuk menyelesaikan permasalahan antara pelaku usaha dan konsumen yaitu melalui jalur diluar pengadilan yang ditegaskan pada Pasal 47 UUPK dan Melalui jalur pengadilan yang ditegaskan pada Pasal 48 UUPK.

Upaya penyelesaian permasalahan antara konsumen dengan pelaku usaha pada umumnya konsumen lebih memilih menyelesaikan sengketa secara jalur kekeluargaan atau secara jalur di luar pengadilan. Hal ini menunjukan bahwa tingkat toleransi konsumen cukup tinggi karena konsumen cenderung menghindari terjadinya sengketa yang berkepanjangan. Upaya mediasi merupakan upaya hukum yang sering konsumen lakukan ketika hak-hak konsumen dirugikan oleh pelaku usaha. 
Sehingga banyak konsumen yang menganggap jalur hukum untuk menggugat pelaku usaha akan memerlukan waktu yang lama.

\section{SIMPULAN DAN SARAN}

\section{Simpulan}

Berdasarkan hasil analisis data dapat disimpulkan bahwa Pemerintah telah memberi perlindungan terhadap konsumen melalui UUPK, dengan adanya UU ini baik konsumen dan pelaku usaha memiliki posisi yang setara dalam perihal hak dan kewajiban. Apabila itu dilanggar oleh pelaku usaha konsumen dapat melaporkannya, yang kedua faktor yang dapat menyebabkan pelaku usaha terhadap terjadinya produk yang memiliki nominal berbeda dari harga pada kemasan terdiri dari faktor internal yaitu pegawai toko lupa untuk memperbaharui atau menempelkan harga yang sama pada kemasan produk dengan saat melakukan transaksi pembayaran dan faktor eksternal yaitu mengenai adanya oknum konsumen dapat melakukan mencabut label harga pada kemasan produk lalu digantinya dengan label yang memiliki nominal lebih rendah dari yang sebenarnya dibayarkan. Upaya penyelesaian dapat melalaui di luar pengadilan dan melalui jalur pengadilan. Tetapi pada umumnya konsumen lebih memilih menyelesaikan sengketa secara jalur kekeluargaan atau secara jalur di luar pengadilan.

\section{Saran}

Dari hasil penelitian di atas, adapun yang disarankan oleh peneliti yaitu diharapkan kepada pelaku usaha dalam menjalankan usahanya seharusnya menunjukkan itikad baik dan memberikan informasi yang jelas atas barang dan atau jasa yang diedarkan serta berupaya memperhatikan hak-hak konsumen dan kewajibannya sebagai pelaku usaha yang telah dirumuskan dalam UUPK dan tidak melanggar larangan-larangan yang telah diatur dalam peraturan perundang-undangan, selanjutnya Konsumen hendaknya bersifat kritis dalam memperjuangkan hak-hak serta berhati-hati dalam membeli produk agar terhindar dari bahaya. Pemahaman hukum perlindungan konsumen perlu ditingkatkan agar kesadaran hukum masyarakat terkait perlindungan konsumen lebih optimal dalam pelaksanaannya.

\section{DAFTAR PUSTAKA}

Ali, M. (2011). Pengawasan Peredaran Barang Cetakan, Due Process Of Law dan Hak Atas Kebebasan Mengeluarkan Pendapat. Jurnal Konstitusi, 8(4), 521-550.

Poernomo, H. S. L. (2020). Analisis Perlindungan Hukum Konsumen Produk Makanan Kemasan yang Beredar di Kota Makassar. Jurnal Law Review, 3(1), 40-58.

Shidarta. (2000). Hukum Perlindungan Konsumen Indonesia. Grasindo. Bogor

Shofie, Y. (2000). Perlindungan Konsumen dan Instrumen-Instrumen Hukumnya. Citra Aditya Bakti.

Sidabalok, J. (2006). Hukum Perlindungan Konsumen di Indonesia. Citra Aditiya.

Sugiyono. (2013). Metode Penelitian Pendidikan Pendekatan Kuantitatif dan Kualitatif. Alfabeta.

Susanto, H. (2008). Hak-hak Konsumen Jika Dirugikan. Visimedia. Bandung

Tobing, R. D. (2015). Hukum Konsumen dan Masyarakat Laskbang. Mediatama Palangkaraya.

Waluyo, B. (2002). Penelitian Hukum Praktek. Sinar Grafika. Bandung

Willy, W., \& Nurjanah, S. (2019). Pengaruh Kemasan Produk Dan Rasa Terhadap Minat Beli Yang Berdampak Pada Keputusan Pembelian Pelanggan Minuman Energi. Jurnal Ilmu Manajemen, 8(2), 65. 